\title{
強化食品中のビタミン $\mathrm{B}_{1}$ 定量に及ぼす バニリンの影響について（第 1 報）
}

簡易チオクロム法におけるバニリンの阻害作用

(昭 和 39 年 8 月 24 日 受 理)

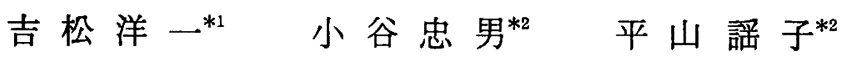

Influence of Vanillin on the Determination of

Vitamin $B_{1}$ in Enriched Foods (I)

Interference of Vanillin on the Simplified Thiochrome Method

Yoichi YOSHIMATSU*1, Tadao KOTANI*2, and Utako HIRAYAMA*2

(*1 Mishima Factory, Morinaga Confectionery Co., Ltd.: 231, Naka, Mishima-shi, Shizuoka-ken; *2 Quality Control Room, Morinaga Confectionery Co., Ltd.:

Shimosueyoshi, Tsurumi-ku, Yokohama-shi, Kanagawa-ken)

On determining vitamin $B_{1}$ in enriched foods added flavours by the simplified thiochrome method, the recovery of vitamin $B_{1}$ was decreased by the interference of vanillin which was often used as flavour and coexisted with vitamin $B_{1}$. However, this interference could be removed, if vitamin $B_{1}$ was purified by Permutit. In the case of colorimetric determination by $p$-aminoacetophenone, the above interference did not show at all.

(Received August 24, 1964)

\section{1. 楮言}

食品添加物として許可され，広く実用に供さ㧈ている 各種ビタミン $\mathrm{B}_{1}$ 塩, $\mathrm{B}_{1}$ 誘導体のうち, ビスケット，ある いはホットケーキミックスの強化用としては, アルカ リ膨剤に対する抵抗力の大きいジベンゾイルチアミン (DBT と略称する) が最も有利なことは周知のところ であろう。これは，その化学構造の特異性によるもので あるが，この特異性が分析する場合に，抽出困難の原因 となったり，あるいは加水分解の必要を生ずるという問 題点もないわけではなかった.しかしこの障害も，川

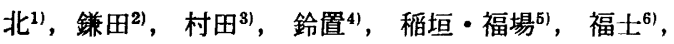
堀》らの研究によって, 次第に克服され, 一応の解答は 得られたかに見える. 一方, 強化食品中の $\mathrm{B}_{1}$ をオクロ ム罃光法によって試験する際に，盲螢光物質の少ない検 体には，バームチット処理を省略した簡易法が用いられ ることが多いようで，上述の諸報告の多くも，この簡易 法について述へている．筆者らはホットケーキミックス

*1 森永製菓株式会社三島食品工場 : 三島市中231

*2 森永製菓株式会社品質検査室 : 横浜市鶴見区下末吉 町 1035
製造にあたって，じん速性に重きを置いて，その管理分 析に堀7)らの簡易チオクロム法を適用したところ, 予想 に反してきわめて低い回収率しか得られなかった。この 原因について検討したところ共存するパニリンがチオク 口ム螢光の発現を妨害することが認められ, 盲螢光物質 の少ない強化食品といえども，簡易チオクロム法を適用 することは，危険な場合が多いことを見いだした。

\section{2. 実験方法と結果}

2.1 ホットケーキミックス中の DBT 簡易定年法 堀7らの方法に準じて，つぎのごとく術式を定めた。 ホットケーキミックス (DBT $0.735 \mathrm{mg} \%$ ) $10 \mathrm{~g}$ をと り，遠沈管に入れ， $0.1 \mathrm{~N}$ 塩酸・70\%エタノール $50 \mathrm{ml}$ で $60 \sim 70^{\circ}, 30$ 分間浸出する. 冷後 $3000 \mathrm{rpm} 5$ 分間遠 心分離し上澄液を $0.1 \mathrm{~N}$ 塩酸・70\%ェタノールで正確に $100 \mathrm{ml}$ とした.この $4 \mathrm{ml}$ を $50 \mathrm{ml}$ の共セン試験管に とり, $\mathrm{N}-\mathrm{NaOH} 2 \mathrm{ml}$ を加え, 正確に20分間アルカリ分 解したのち, N-HCl $2.4 \mathrm{ml}$ を加える.これに氷冷 $\mathrm{BrCN}$ $6 \mathrm{ml}$ を加えて混合し，続いて $30 \% \mathrm{NaOH} 4 \mathrm{ml}$ を加え て混合する.つぎにイソブタノール $20 \mathrm{ml}$ を加えて, 約 100 回激しく振り抽出する. 1.5 時間暗所に静置し，上層 
をピベットでとり，口紙でろ過後，螢光を測定才すく 女找光電比色計 5 号 D型, 螢光湘这補助装置在用(つ).

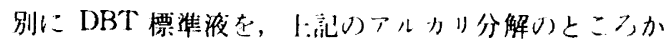

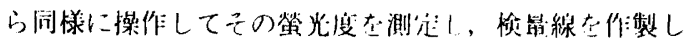
て試料币の DBT 含量を求める.

\section{2 分析耛果}

製造月日の異なる製品を選び，分析したところ，第 1 表に示すようにきわめて低い同収率（30４0\%）しか得 られず，抽出回数を增しても，絬果は同じであった。

第 1 表 㩦易定量法による製品分析㑬

\begin{tabular}{|c|c|c|c|c|c|c|c|}
\hline 武 & 料 & $の$ & 種 & 類 & 理論倠 & 分析值 & 间收率 \\
\hline 摽 & & 準 & 1 & & $\begin{array}{c}\mu \mathrm{g} / \mathrm{ml}{ }^{*} \\
1.45\end{array}$ & $\begin{array}{l}\mu \mathrm{g} / \mathrm{ml} \\
1.45\end{array}$ & $100.0^{\%}$ \\
\hline 標 & & 準 & 2 & & 1.00 & 1.13 & 113.0 \\
\hline 嫩 & & 準 & 3 & & 0.75 & 0.75 & 100.0 \\
\hline 製品 A & （抽 & 出 & 1 & 回) & 0.735 & 0.28 & 38.1 \\
\hline 製品 B & （抽 & 出 & & 回） & 0.735 & 0.29 & 39.5 \\
\hline 製品 C & （抽 & 出 & 1 & 回) & 0.735 & 0.27 & 36.8 \\
\hline 製监D & (抽) & $\begin{array}{l}\text { 出 } \\
50\end{array}$ & $\underset{\mathrm{ml}}{2}$ & 回 & 0.735 & 0.24 & 32.7 \\
\hline 製品 $\mathrm{E}$ & $\left(\begin{array}{l}\text { 抽 } \\
40,\end{array}\right.$ & $\begin{array}{l}\text { 出 } \\
30 \text {, }\end{array}$ & & & 0.735 & 0.25 & 34.0 \\
\hline
\end{tabular}

* 採取検液 $1 \mathrm{ml}$ (=製品 $0.1 \mathrm{~g}$ 中) の DBT $\mu \mathrm{g}$ 数

な㧍この操作による DBT の検量線は，第1网に示

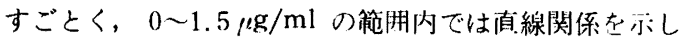
た.

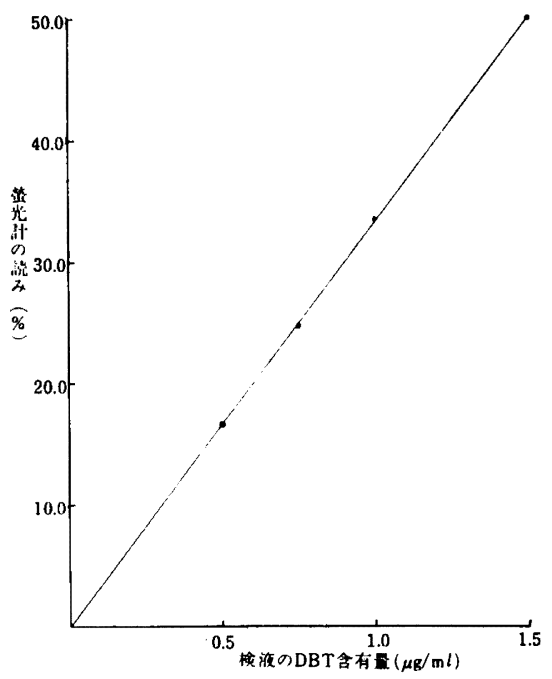

第 1 图 DBT の検量線

2.33 種類の主原料配合品に対する DBT の添加実験

筆者らの得た分析优が, 類似食品であるクラッカー,
スップ、食パン等について報告されている DBT 検出率， 95ー100\%に比いて低すぎ?ので，口ス，バラッキ等を

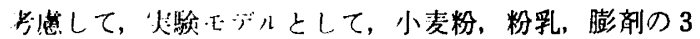

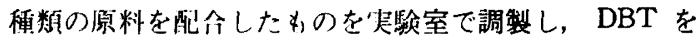
添加して分析したところ第 2 表のごとくきわめて良好な 问収等で検出された。

第 2 表 3 種類の主原料配合品に対する DBT の添加実験

\begin{tabular}{|c|c|c|c|c|c|c|c|}
\hline \multicolumn{2}{|c|}{ 試料の種類* } & 理 & 論 値 & 分 & 析 值 & 回 & 収 䧱 \\
\hline 試 料 & A & & $\begin{array}{l}\mu \mathrm{g} / \mathrm{ml} \\
1.50\end{array}$ & & $\begin{array}{l}\mu \mathrm{g} / \mathrm{ml} \\
1.39\end{array}$ & & $92.6^{\%}$ \\
\hline 陚 料 & B & & 1.00 & & 0.97 & & 97.0 \\
\hline 試 料 & $\mathrm{C}$ & & 0.75 & & 0.73 & & 97.4 \\
\hline 試 料 & $\mathrm{D}$ & & 0.50 & & 0.49 & & 98.0 \\
\hline
\end{tabular}

*試料はそれぞれ配合品 $10 \mathrm{~g}$ に対して, DBT 標準液 を, $150 \mu \mathrm{g}$ (A), $100 \mu \mathrm{g}$ (B), $75 \mu \mathrm{g}$ (C), $50 \mu \mathrm{g}$ (D) 添加したもの

\section{4 小麦粉強化浏の回収実験}

ホットケーキミックスには, DBT 含有小麦粉強化剤 を使用しているので，念のためにこの強化剈での回収実 験を契施した（強化削中の DBT 含量は $37.0 \%$ ）

ロットの異なる小麦粉強化剂を, 少量添加実験におけ るひょう量誤差を避けるために食塩で10倍に希釈混合し 歹記 3 種の主原料配合品に添加, 回収実験を行なった。

この結果も，第 3 表に示すごとく，回収率はいずれも 良姄であり，また強化剤を10倍に希釈混合しただけのも のも, 正常な分析值を示し, 強化剤中の DBT 含有量は 表記のとおりであることが確認された。

第 3 表 小麦粉強化剂の回収些験

\begin{tabular}{|c|c|c|c|c|c|c|c|}
\hline \multicolumn{2}{|c|}{ 武料の種類* } & 理 & 論 值 & 分 & 析 值 & 回 & 収率 \\
\hline 試 料 & A & & $\begin{array}{l}\mu \mathrm{g} / \mathrm{m} \\
0.74\end{array}$ & & $\begin{array}{l}\mu \mathrm{g} / \mathrm{m} \\
0.73\end{array}$ & & 98.7 \\
\hline 試 料 & B & & 0.74 & & 0.72 & & 97.3 \\
\hline 試 料 & $\mathrm{C}$ & & 0.74 & & 0.73 & & 98.7 \\
\hline 試 料 & $\mathrm{D}$ & & 0.74 & & 0.74 & & 100.0 \\
\hline
\end{tabular}

* 試料 A， B は 3 種原料配合品 $10 \mathrm{~g}$ に強化剂希釈混合 品 $20 \mathrm{mg}$ 添加したもの, 試料 C,Dは強化剤を食塩 で10倍に希积しただけのもの $20 \mathrm{mg}$

\section{5 試作配合品およひ副原料類に対する小麦粉強 化剂の添加実験}

主原料でのモデル実験では, 回収率は良好であり，ま た DBT 自体の高い安定性, それに詳細なデータは省略 するが、バラッキをチェックした工程間の多数回の試験 結果は, 回収乷こそ低いが，いずれも一様な測定值を与 えることから，DBT の低い回収率は，簡易チオクロム 
法での定量を阻害する物質の共存によるものと教えざる をえない，そこで筆者らはこの阻害物質を探し出す目的 で、ホットケーキミックスの配合を部分的に変えた，

試作品 $\mathrm{A}$ ：基準配合から, 油脂, 強化骫およびビタ ข $\mathrm{B}_{2}$ を除外

試作品 $\mathrm{B} ：$ 基準配合から，バニリン粉小否料，強化骫 およびビタミン $\mathrm{B}_{2}$ を除外

を作りこれに強化剤を添加して回収実験を陚みた。な 㧍, 副塬料の一部についても, それぞれ単独に強化剂を 加えて回收実験を行なった．絬果は第 4 表のごとくであ る.

第 4 表 少量涯加物等への小麦粉強化刘の涯加止唻

\begin{tabular}{|c|c|c|c|}
\hline 試 料 の 種 類 & 理論值 & 分析値 & 回収率 \\
\hline 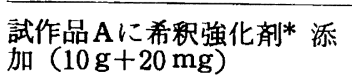 & $\begin{array}{r}\mu \mathrm{g} / \mathrm{ml} \\
0.74\end{array}$ & $\begin{array}{r}\mu \mathrm{g} / \mathrm{ml} \\
0.26\end{array}$ & $\begin{array}{r}\% \\
35.2\end{array}$ \\
\hline $\begin{array}{l}\text { 試作品 Bに希秎強化剈添加 } \\
(10 \mathrm{~g}+20 \mathrm{mg})\end{array}$ & 0.74 & 0.72 & 97.4 \\
\hline 希釈添加剤 $20 \mathrm{mg}$ & 0.74 & 0.75 & 101.3 \\
\hline 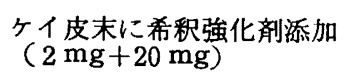 & 0 . & 0.69 & 93.3 \\
\hline $\begin{array}{l}\text { 卵白粉末に希啋強化剂添加 } \\
(10 \mathrm{mg}+20 \mathrm{mg})\end{array}$ & 0.74 & 0.75 & 101.3 \\
\hline
\end{tabular}

* 小麦粉強化剂を食塩で10倍に希釈 (以下间様)

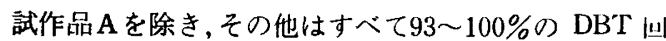
収率を示している，ところが陚作品 $\mathrm{A}$ のみは，今までの 分析値と同様 $35 \%$ と低い回収率であった。

試作品 $\mathrm{A}$ と B の相違点はバニリン粉末否料を含有する か否かの差である.このことから DBT 㨫収采不良の原 因はパニリン粉末香料の存任にあることが推定される.

\section{6 小麦粉強化剂にパニリン粉末香料およびバニ リンの添加実験}

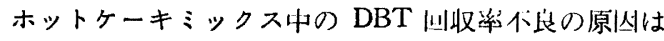
バニリン粉末否料の共存によるものらしいことがわかっ たので，小麦粉強化剤にこのものを添加して確認头軨を 行なった..

なおぐニリン粉末香料は， バニリンと付加物質から成 るため,このうちのどれが定量を阻害しているかを確か

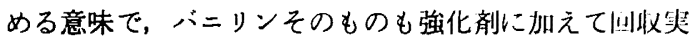
験を行なった。結果は第 5 竝に示すように，バニリン粉

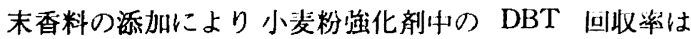
はなはだしく低下する。この低下の度合は，バニリン粉 末香料の添加量が多くなるほど大きい。.また純バニリン の添加では，回収率はほとんど 0\%近くまで下ってしま うことより，阻害物質はバニリン粉术否料の们加物質で はふくハニリンそのおのであると考えられる。
第 5 表 小类粉強化剤にバニリン関係添加物の添加実験

\begin{tabular}{|c|c|c|c|}
\hline 試料の種類 & 理 論 値 & 分析値 & 回収率 \\
\hline 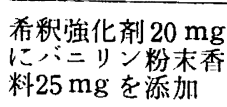 & $\begin{array}{c}0.74 \mu \mathrm{g} / \mathrm{ml} \\
\left(\text { ハ }=1 V^{\prime} 2.31\right. \\
\mu \mathrm{g} / \mathrm{ml})\end{array}$ & $\begin{array}{r}\mu \mathrm{g} / \mathrm{ml} \\
0.22\end{array}$ & 29.8 \\
\hline 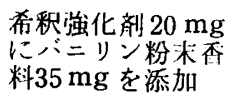 & $\begin{array}{c}0.74 \\
(\text { ハ }=\text { i) } ン 3.23 \\
\mu \mathrm{g} / \mathrm{ml})\end{array}$ & 0.13 & 17.6 \\
\hline $\begin{array}{l}\text { 希积強化剂 } 20 \mathrm{mg} \\
\text { を涯加 }\end{array}$ & $\begin{array}{c}0.74 \\
(\therefore=\text { i } \because 7.43 \\
\mu \mathrm{g} / \mathrm{ml})\end{array}$ & 良 跡 & 0 \\
\hline
\end{tabular}

\section{7 その他の $\mathrm{B}_{1}$ 類定目に及ばすバニリンの影霎}

DBT の定量におけるバニリンの阻害作用については, 今までの笑駼で明らかになったが，その他の $\mathrm{B}_{1}$ 塩類に 対するバニリンの影繁はどうかということを調べた。使 用した $\mathrm{B}_{1}$ 塩頑は，（イ） $\mathrm{B}_{1}$ ・硝凌塩，（口） $\mathrm{B}_{1} \cdot$ 口ダ ン監, (ハ) $\mathrm{B}_{1}$ ・ナフタリン-1,5-ジスルホン酸塩(NDS と略称する）の 3 種類である.

\subsection{1 $B_{1}$ をバニリンと共存させた場合の回収実験}

3 種類の $\mathrm{B}_{1}$ 塩について, バニリン無源加のものと, それぞれについて盐酸チアミン ( $\mathrm{B}_{1}$ と略称する) 換算刘 比として一定量のバニリンを添加したものとの 2 組に対 して, 後記するようにいろいろの $\mathrm{B}_{1}$ 分析法を尖施し阻 害作用の有無を調べた。

\section{（a）チオクロム螢光法の場合}

純品に刘する試験法をフェリシアン化カリによる酸化 法 $^{81}$ と $\mathrm{BrCN}$ による酸化法99について箺施した結果は第 6 装に示すごとくで，程度の差はあるが，いずれも著し く阻害作朋を受けることが判明した。なおこの場合は純 品に対する試験であるので, 当然のことながら, パーム チットによる精製は行なっていない。

第 6 表 純 $\mathrm{B}_{1}$ 塩類のチオクロム法による試数に 及路すバニリンの影響

\begin{tabular}{|c|c|c|c|c|}
\hline \multirow{3}{*}{ 陚料の種颣! } & \multicolumn{4}{|c|}{ 得られた螢光の道さ } \\
\hline & \multicolumn{2}{|c|}{ 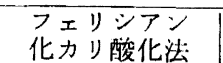 } & \multicolumn{2}{|c|}{$\mathrm{BrCN}$ 酸化法: } \\
\hline & 純 品 & $\begin{array}{l}=112 \\
=10\end{array}$ & 純 品 & $\begin{array}{l}:=y= \\
=10\end{array}$ \\
\hline 硝凌塩 & 100.0 & 56.3 & 100.0 & 19.1 \\
\hline 口ダン喥盐 & 100.0 & 0.4 & 100.0 & 14.0 \\
\hline NDS & 100.0 & 50.9 & 100.0 & 6.0 \\
\hline
\end{tabular}

\section{（b） ジアゾ比色法101の場合}

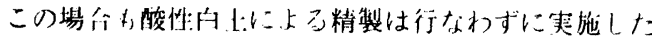
が，絬果は第 7 表に示才二とく，ミニリン添加の有無に

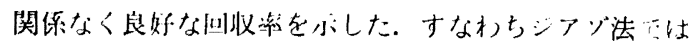


バニリンの存在は $\mathrm{B}_{1}$ 定量になんの影響も及ぼさないわ けである.

第 7 表 純 $\mathrm{B}_{1}$ 塩類のジアゾ法による試験に 及ぼすバニリンの影響

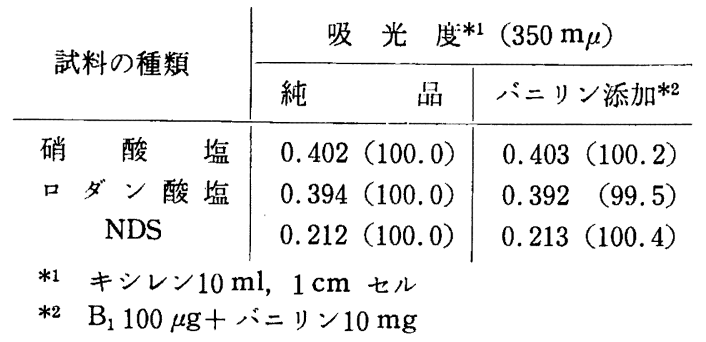

\section{7 .2 パームチット精製・BrCN 酸化によるチオ クロム法へのバニリンの影響}

強化食品中の $\mathrm{B}_{1}$ 塩類をチオクロム螢光法で定量する 際, 盲螢光物質を除くためにパームチットで精製するの が最も標準的であるとされている，一方，周知のように ハンリンは食品香料中で一番普通に使用される香料であ $\eta$, 当然 $B_{1}$ 強化菓子類にも広く使用されていると考え られる。 それにもかかわらず，今まで，これの阻害作用 が問題とならなかったのは（1)パームチット処理によっ てバニリンが除かれてしまうためか一筆者らの場合, 対象となる製品にバニリンを含むものが多いにもかかわ らず，今まで問題を生じなかったのは, 従来 $\mathrm{B}_{1}$ 定量の 際には, DBTを含めて, すべてパームチット処理を行 なっていたためであろうと考えられる一，(2)パーム千 ット処理を省略した場合は, $\mathrm{B}_{1}$ の低い検出值は, すべて 製造時のロスと誤認されたか，(3)またとくにパームチッ 卜処理の省略されることの多いDBT の場合は, その抽 出の困難さのために，バニリンの影響が見すごされてき たかのいずれかであろう。このうちパームチット処理の 効果を確認するため, つぎのような 2 種類のホットケー キミックスのモデル試料

（1）基準配合から小麦粉強化剤，バニリン粉末香料を

除外したもの,

(可 基準配合から小麦粉強化剤のみを除外したもの を作り、これに2.7.1 で使用したのと同じ 3 種類の $\mathrm{B}_{1}$ 塩 を $\mathrm{B}_{1}$ 換算 $0.5 \mathrm{mg} \%$ 相当量添加し， $\mathrm{BrCN}$ によるチオク 口ム法で回収率を調べた。

結果は第 8 表に示すごとく，すべてに良好な回収率が 得られ, パームチット処理によってバニリンの妨害作用 は完全に排除されることがわかった。

\section{3. 総 括}

(1) ホットケーキミックス中の DBT を定量するとき 簡易定量法では回収率が著しく低下する（30〜40\%).
第 8 表 パームチット処理・ $\mathrm{BrCN}$ 酸化チ オクロム法による分析値

\begin{tabular}{|c|c|c|}
\hline$\underline{\underline{x}}$ & 試料の種類 & $\begin{array}{l}\text { 得られた螢光 } \\
\text { の強さ }\end{array}$ \\
\hline バニリン無添加 & $\begin{array}{c}\text { 硝 酸 塩 } \\
\text { ロダン酸 塩 } \\
\text { NDS }\end{array}$ & $\begin{array}{r}95.7 \sim 100.0 \\
98.3 \sim 100.1 \\
100.0 \sim 100.1\end{array}$ \\
\hline バニリン 添加 & $\begin{array}{cc}\text { 硝 酸 塩 } \\
\text { ロ ダン酸 塩 } \\
\text { NDS }\end{array}$ & $\begin{array}{r}97.5 \sim 100.1 \\
100.2 \sim 100.3 \\
100.0 \sim 100.3\end{array}$ \\
\hline
\end{tabular}

(2) この原因について, 浸出回数, 製造工程, 原料等 について検討した結果, 共存するバニリンが阻害作用を 及ぼしていることがわかった。

（る）バニリンは簡易チオクロム法による場合，すべて の $\mathrm{B}_{1}$ 類に対して阻害作用を及ほすす。

（4）ジアゾ法はバニリンの阻害作用を受けない，

（5）チオクロム法の場合，バニリンはパームチット吸 着によって除かれ，定量に支障を与えなくなる.

(8) DBT の場合も，アルカリ分解後，パームチット 処理を行なうことによって始めて正しい回収率が得られ る.これについては，バニリンの阻害の原因とともに, 後報で述べることにする.

文献

1）川北兵蔵, 林 右市：ビタミン14, 1199, 202, 894 (1958)；16, 753 (1959); 川北兵蔵：醗酵工 学38, 207, 260, 267 (1960).

2）豏田政喜, 堀正剛：武田年報 14, 19 (1955).

3）村由希久, 山野敏子：ビタミン13，105 (1957).

4）鈴置二郎，鈴置恒子，栗原美栄子：同上 7, 120 (1953).

5）稲垣長典，福場博保：同上 13，74，553 (1957); 17, 17 (1959); 稲垣長典, 福場博保, 宮川尚子 : 同上 17, 20 (1959); 稲垣長典, 福場博保, 岩 田祥子: 同上 17, 23 (1959).

6）福士敏雄：同上 25, 225 (1962).

7）堀正剛, 青木勇: 同上 25，225 (1962).

8）食品添加物公定輩註解編集委員会：“食品添加物 公定書註解” 387，392，396，398（1961）金原出 版.

9）八木国夫編：“最新ビタミン定量法”19（1954） 医齿薬出版.

10）永原太郎，岩尾裕之：“食品分析法” 186 (1962) 柴田書店。 